|Araştırma Makalesi / Research Article|

\title{
Turizm İşletmeciliği Bölümü Öğrencilerinin Uygulamalı Mutfak Derslerine İlişkin Tutumları Ve Ders Çıktılarına Yönelik Bir Araştırma
}

\section{A Study on the Attitudes of the Tourism Management Students to Applied Culinary Classes and Course Outcomes}

\section{Çetin AKKUŞ ${ }^{1}$}

Anahtar Kelimeler
uygulamalı mutfak
dersleri
turizm işletmeciliği
öğrencileri
restoran müşteri
memnuniyeti

\section{Keywords}

practical kitchen classes

tourism management students

customer satisfaction at the restaurants

\section{Başvuru Tarihi/Received} 23.03.2019

Kabul Tarihi /Accepted 29.04.2020
Öz

Turizm sektörü, önemli hizmet alt sektörlerinden biri olup, bu sektörün istihdamına katkı sunacak personelin gerekli mesleki donanıma sahip olması elzemdir. Ancak özellikle fakülteler nezdinde turizme yönelik mesleki eğitim çeşitli sebeplerden ötürü ikinci planda kalmaktadır. Bu durum zaman içerisinde öğrencilerin sektörün işleyişinden uzaklaşmasına ve özellikle stajlar ile tanıştığı turizm hizmetlerinden soğumasına sebep olmaktadır. Bu nedenle özellikle fakültelerde mesleki eğitime yönelik uygulamalı derslerin verilmesi ve bu derslere yönelik bir bilinç aşılanması önem arz etmektedir.

$\mathrm{Bu}$ araştırmada, Kastamonu Üniversitesi Turizm Fakültesi Turizm İşletmeciliği bölümü öğrencilerinin uygulamalı mutfak eğitimine ilişkin tutumları ile öğrencilerin uygulamalı mutfak dersleri kapsamında sunduğu hizmete yönelik müşteri memnuniyetini tespit etmek amaçlanmıştır. Buna binaen öğrencilerin dersi almadan önce ve aldıktan sonraki tutumlarında; ders kapsamında sunulan hizmete yönelik müşteri memnuniyeti ile normal zamanda sunulan hizmet arasındaki memnuniyet düzeyinde herhangi bir farklılık olup olmadığı ölçülmüştür. Araştırma kapsamında toplam 170 öğrenci anketine ve toplam 495 müşteriye ulaşılmıştır. Araştırma 2017-2018 güz yarıyılı içerisinde gerçekleştirilmiştir. Araştırma sonucunda, öğrencilerin uygulamadan önceki ve sonraki düşüncelerine ilişkin faktör ortalamaları arasında istatistiksel olarak anlamlı farklılıklar tespit edilmiştir. Mutfak personelinin sunduğu hizmet ile ders kapsamında sunulan hizmete yönelik müşteri memnuniyetinde personel kalitesi, hizmet kalitesi ve genel memnuniyet açısından anlamlı farklılık tespit edilmiştir.

\section{Abstract}

The tourism sector is one of the significant service subsectors, and it is crucial that the employees belonging to this sector have the necessary professional skills. However, vocational training, especially at the faculty level, is still secondary for-several reasons. In time, this causes students to distance themselves from the way the sector operates and they become alienated from the tourism sector, to which they are introduced through internships. Therefore, it is crucial that practical classes are offered especially at the faculty level to contribute to students' vocational training and increase their awareness about these classes.

The purpose of this study is to examine the thoughts of students at the Tourism Management Department in the School of Tourism at Kastamonu University on practical kitchen classes and customer satisfaction with the services provided by students within these classes. In this aspect, we measured whether a difference between students' thoughts before and after taking the class was present and whether there was a difference between customer satisfaction towards the services provided as part of the classes and the level of satisfaction towards the services provided under normal circumstances. Surveys were completed by 170 students and 495 customers. The study was conducted in the Fall semester of the 2017-2018 academic year. Through this study, we determined that there is a statistically significant difference between the factor means of students' thoughts before and after the practice. We found a significant difference between customer satisfaction with the services provided as part of the class and customer satisfaction with the services provided by the kitchen personnel regarding personnel quality, service quality, and overall satisfaction. 
Extended Abstract

\section{Introduction}

Education is crucial in every sphere of life, vocational training, which aims at enabling individuals to perform a particular vocation, is very useful since it systematically contributes to employment. Therefore, vocational training in the tourism sector, as a subbranch of the service sector, is significant. This includes not only theoretical training about the kitchen, service, front desk and housekeeping but also training about concepts and qualifications that cannot be comprehended without practice. Therefore, practical classes need to be included in the curricula especially at schools offering tourism, making it possible for students to gain enough practice opportunities during the classes and thereby becoming more qualified for future employment. Since schools of tourism have a philosophy of training managers, their fields of application are usually limited. This causes a significant disadvantage for those who did not graduate from a vocational high school and who have been involved in the tourism sector for the first time. This leads to students' distancing themselves from the sector as soon as they join it. Therefore, it is particularly important that vocational training is provided particularly at schools of tourism.

\section{Method}

This study adopted a quantitative design through the survey method. We used the survey form developed by Çemrek and Yılmaz (2010) consisting of 25 expressions to determine students' thoughts on the practical kitchen classes. We prepared a survey form consisting 16 questions to measure customer satisfaction, which inquired about the quality of the food, service quality and customer satisfaction. We adopted 13 expressions about the quality of the food and service quality from Yüksel and Yüksel's (2002) study. The authors created three expressions included in the customer satisfaction dimension. This form did not include any demographical variables about customers since it was not necessary for the purposes of this study. Both forms were used at two different stages. A total of 85 survey forms were completed and submitted by the students at the beginning of the semester before the first class started. The same survey forms were completed by the same students at the end of the semester (four months later), and again, 85 survey forms were collected. We collected a total of 170 survey forms; half before the start of the class and the other half at the end of the semester. Thrice a week throughout the semester, students had practice sessions for various cuisines in groups of 10 . The students were not limited to certain cuisines and they made the decision regarding the cuisines their practical training would cover. The practical training was conducted at the kitchen of the guesthouse in the School of Tourism, and the students presented their food prepared to the guests who visited the guesthouse for lunch. The guests completed 265 survey forms during the practical training; however, after eliminating incomplete survey forms, 259 survey forms were taken into evaluation. During regular business hours, 238 survey forms were completed. As a result, 495 survey forms were obtained.

\section{Findings:}

We determined that there was a statistically significant difference between the factor means of the students' thoughts before and after the practice $(p<0.05)$. We found that students were ambivalent on all the factors prior to the classes; however, when after collecting their thoughts again after the classes, they had more positive opinions and higher values. We did not find any significant difference in Food Quality between services provided under normal circumstances by professional staff and services provided by students as part of the practical kitchen class $(t=$ $1.606, p=0.109)$. There was a significant difference on Staff Quality between the service provided by professional staff and the service provided as part of the classes $(t=2.227, p=0.026)$. There was a significant difference between the Service Quality provided by the students and the professional staff on customer satisfaction $(t=3.640, p=0.000)$. When we examined the overall satisfaction with the services provided at the restaurant, we observed that there were differences between the averages $(t=2.090, p=0.037)$. We concluded that the customers were more satisfied with the services provided by students.

\section{Result and Discussion}

When we considered the differences between the averages, we observed that the biggest difference was between students' thoughts on the necessity of the practical kitchen classes. In other words, after they took the class, students expressed that the class was necessary and the period of the class should be longer than what was offered. Similar to the results of the study conducted by Kang (2011:475), we found that the students had a high demand for learning and they requested training that was more practical. One of the most critical issues for students was professors' who were supportive and encouraging. Kang's (2011: 475) study indicated that teachers were very important for the way classes were conducted, and there was a need for more educational support to their professional competencies. We found no difference between the services provided by the students and the services provided by professional staff regarding the quality of the dishes they prepared. This is important because it suggests that the students were able to prepare dishes which were as good as the professional, experienced staff in the sector. We observed that students took their responsibilities very seriously and showed the necessary sensitivity when they were provided with the necessary opportunities and training. This was reflected in the quality of the dishes they prepared which in turn led to customer satisfaction that was not different from the usual. In addition, there were differences in customer satisfaction with the service provided by students and professional staff regarding the other three factors. However, all these differences are to the students' advantage and indicate that customers' satisfaction towards the services they provided had higher means. Overall, the customers were more satisfied with the services provided by the students as compared to the services provided by professional staff. Thus, it is possible to argue that students' possible thoughts about the class were reflected in the customers and that the students completed the training success fully. 
GíRiş

Turizm sektörü sağladığı birçok olumlu katkı sebebiyle hem gelişmiş hem de gelişmekte olan ülkeler açısından oldukça önemli bir sektördür. Özellikle ekonomik anlamda sağladığı faydalar, daha net bir şekilde etkisini ortaya koymaktadır. Turizm endüstrisi 2016 yılında küresel GSYH'nin \%10,2'sini oluşturarak ekonomiye 7,6 trilyon dolar katkıda bulunmuştur. 2015 'de 46 milyonu aşan uluslararası varışlar 2016 yılında 1.2 milyara ulaşmıştır. 2030 yılına kadar bu rakamın 1.8 milyara ulaşacağı tahmin edilmektedir. 2016 yılında dünyadaki her 10 istihdamdan biri ile toplamda 292 milyon istihdam yaratmıştır. Şimdiden sektörde neredeyse iki kat daha fazla kadın istihdam edilmektedir. Araştırmalar her 30 yeni turist ile yeni bir istihdam yaratıldığını göstermektedir (WEF, 2017: 3). Uluslararası varışlar arttıkça turizm sektöründe yeni iş kollarının ve istihdam oranının artacağı, özellikle kadın çalışan nüfusuna önemli bir katkı sağlanacağı açıktır.

Türkiye'nin ise 2017 yılında uluslararası turist varışları 32 milyon olarak gerçekleşmiş, uluslararası turizm geliri ise 20 milyon \$’ geçmiştir (TÜiK, 2018). Aynı yıl turizm endüstrisi GSYH'sı 35 milyon \$ olup, bunun toplam GSYH içindeki payı \%5'dir. Turizm istihdamı ise yaklaşık 600 bin olarak gerçekleşmiştir. Turizm istihdamının toplam istihdama oranı \%2.3'dür (WEF, 2017: 326). Türkiye turizme bu kadar bağımlı iken, sektörün gelişimi için yetişen personelin kalifiye olması da oldukça önemlidir. Bu sebeple verilen eğitimin ne kadar önemli olduğu daha açık bir şekilde anlaşılmaktadır. Eğitim bireylerin gelişimini desteklerken toplumların kalkınmasına da etki eden oldukça önemli ve vaz-geçilmez bir faktördür. Hayatın her alanında eğitim oldukça önemli olmakla birlikte, kişileri bir işi yapabilir seviyeye getirmeyi amaçlayan mesleki eğitimler istihdama sistemli bir katkı sunmak açısından oldukça faydalıdır. Bu sebeple hizmetler sektörünün önemli alt dallarından biri olan turizm sektöründe de mesleki eğitimlerin büyük önem arz ettiği söylenebilir. Bunlar mutfak, servis, ön büro, kat hizmetleri gibi teorik bilgi yanı sıra pratik bilgi olmadan tam anlamıyla kavranamayacak ve yetkinlik elde edilemeyecek derslerdir. Bu sebeple özellikle turizm fakültelerinde müfredatlara uygulamaya dönük derslerin eklenmesi ve derslerde yeterli pratik yapılmasının önü açılarak geleceğin sektör çalışanlarının daha kalifiye hale getirilmesi gerekmektedir.

Turizm fakülteleri yönetici yetiştirme odaklı bir felsefeye sahip olduğu için genellikle uygulama alanları kısıtlıdır. Bu durum özellikle meslek lisesi mezunu olmayan ve ilk defa turizm eğitimine dâhil olan öğrenciler açısından büyük bir dezavantaj yaratmakta ve öğrenci sektöre adım atar atmaz işten uzaklaşmaktadır. Bu sebeple özellikle fakülteler nezdinde turizme yönelik mesleki eğitimin verilmesi büyük önem arz etmektedir.

Bu araştırmada turizm işletmeciliği bölümü öğrencilerinin “Uluslararası Mutfaklar” dersi kapsamında yapılan uygulamalı mutfak eğitimine yönelik ders öncesi ve sonrası tutumlarını tespit etmek amaçlanmıştır. Öğrencilerin ders kapsamında ne kadar verimli bir faaliyet içerisinde olduklarını tespit edebilmek için ise ürettiği ve restoranda sunduğu yemeklere yönelik müşteri memnuniyeti ölçülmüştür. Bununla birlikte öğrencilerin ders kapsamında sunduğu hizmete yönelik müşteri memnuniyeti ile normal zamanda sunulan hizmet arasındaki memnuniyette herhangi farklılık olup olmadığı da analiz edilerek araştırma sonuçları pekiştirilmiştir.

\section{Türkiye'de Lisans Düzeyinde Mesleki Turizm Eğitimi}

Bireylerin yüksek yaşam standartlarına ulaşabilmesi, toplumların ilerleyebilmesi ve gelişmiş ülkeler içerisinde yer alabilmesi için eğitim öncül aktörlerden biridir. Mesleki eğitim ise henüz uzman sayılamayan ya da yarı uzman işgücünü, uzmanlık gerektiren ve özel nitelikteki işlere hazırlamak amacıyla yapılan çalışmaların tümü (Olcay, 2008: 384) olarak nitelendirilmektedir. Her sektörde olduğu gibi turizm sektöründe de mesleki eğitim büyük önem taşımaktadır. Turizmde mesleki eğitim ya da mesleki turizm eğitimi genel eğitimin bir parçası olarak görülmelidir. Ancak turizm sektöründe verimliliği artırmak, turiste doğrudan hizmet sunmak, personele yetki, yetenek ve sorumlulukları arasında denge kurmayı sağlayacak davranış standartlarını kazandırmak gibi birçok değişken açısından niteliği farklılaşmaktadır (Aksu ve Bucak, 2012: 9).

Türkiye'de mesleki turizm eğitimi yaygın eğitim ve örgün eğitim olmak üzere ikiye ayrılmaktadır. Yaygın eğitim Kültür ve Turizm Bakanlığı, Millî Eğitim Bakanlığı ve çeşitli vakıf ve özel kuruluşlar tarafından verilen sertifikasyon eğitimlerini kapsamaktadır. Örgün eğitim ise Millî Eğitim Bakanlığı ve Yükseköğretim Kurumu tarafından verilen diplomaya dayalı eğitimlerdir. Örgün eğitim içerisinde Millî Eğitim Bakanlığı ortaöğretim düzeyinde Otelcilik ve Turizm Meslek Liseleri ile ilgili eğitim faaliyetlerinden sorumlu iken, Yükseköğretim Kurumu önlisans, lisans ve lisansüstü düzeyde mesleki turizm eğitiminin verilmesi ile ilgilenir. Lisans düzeyinde verilen mesleki turizm eğitimi Turizm İşletmeciliği ve Otelcilik Yüksekokulları ile Turizm Fakülteleri tarafından gerçekleştirilmektedir (Hacıŏlu, N. 1992; Akt. Hacıoğlu, N. vd., 2008: 26).

Türkiye'de lisans düzeyinde verilen mesleki turizm eğitimlerinde amaç turizm sektöründeki işletmelere bilgili, yabancı dil bilen, yetkin yönetici veya yönetici adayları yetiştirmektir (Akoğlan Kozak, 2009). Orta ve üst kademe yönetici yetiştiren yüksekokul ve fakültelerde öğrenimini tamamlayan yönetici adaylarından işletme içi işlerin gerektirdiği teknik ve özel bilgilere sahip olması beklenmektedir (Ural ve Pelit, 2002). Bu sebeple Turizm fakültelerinde verilen dört yıllık mesleki turizm eğitimini alan öğrenciler genellikle üst kademe turizm personeli yetiştirmeye yönelik müfredatlara tabi tutulmaktadır. Ortaöğretim ve önlisans düzeyinde turizm eğitimi alan öğrencilerin ise alt ve orta kademe turizm personeli yetiştirmeye yönelik eğitimlere tabi olduğu bilinmektedir (Gürdal, 2002).

Türkiye'de yükseköğretim düzeyinde turizm eğitiminin sorunlarına ilişkin birçok konferans düzenlenmiştir. Özellikle düzenli aralıklarla 1992, 2002 ve 2012 yıllarında yapılan “Turizm Eğitimi Workshop - Konferans"'larda yükseköğretim düzeyinde turizm eğitimi tartışılmış ve birçok sorun tespit edilmiştir. Tartışılan başlıklar içerisinde sıklıkla mesleki turizm eğitimin önemine değinildiği gözlenmektedir. 
1992 yılında yapılan konferansta yükseköğretim düzeyinde turizm eğitimi veren kurumların eğitim programları yetersiz bulunmuş ve ders konularının çoğunlukla ekonomik ve politik disiplinler çerçevesinde işlendiğinden bahsedilmiştir. Kurumların tam teşkilatlı bir uygulama merkezine sahip olmamaları sebebiyle ders programlarında teorikten uygulamaya geçilemediği belirtilmiştir. Ayrıca yıllar itibariyle ders veren öğretim elemanlarının hizmet özelliklerine uygun yetişmemekle birlikte iş deneyimlerinin de yeterli düzeyde olmadığı ve turizm bölümü kontenjanlarının fazla olmasının uygulamalı derslerin yürütülmesini ve staj imkânını engellediğine değinilmiştir (Arsoy, 1992; Boyacı, 1992; Illkiz ve Hitay; 1992; Kozak, 1992; Külahçı, 1992; Özmerzi ve Ayata, 1992; Timur, 1992).

2002 yılında yapılan konferansta ise yine benzer sorunlar gündeme gelmiş ve yükseköğretim düzeyinde turizm eğitimi veren kurumların fiziksel ortam açısından bazı problemleri olduğu dile getirilmiştir. Bununla birlikte yükseköğretim kurumlarında turizm eğitimi veren kariyer sahibi öğretim elemanı açı̆̆ı bulunduğu ve bu sebeple ders programlarında uygulama derslerinin yetersiz kaldığına vurgu yapılmıştır. Mesleki tecrübeye sahip olmayan öğretim elemanlarının öğrencilerin yapması gereken uygulamalarda yönlendirme yapamadığından ve öğrencilerin bu sebeple gerçek anlamda sektörü tanıyamadığından da bahsedilmiştir (Ahipaşaoğlu vd., 2002; Avcıkurt ve Karaman, 2002; Gökdeniz vd., 2002; Gürdal, 2002; Küçüktopuzlu, 2002; Tuna, 2002).

2012 yılında yapılan konferansta ise özellikle öğrencilerin stajlarda yaşadığı sıkıntılar gündemi oluşturmuştur. Bunun en önemli sebeplerinden biri olarak da özellikle lisans düzeyinde turizm eğitimi veren kurumlarda öğrencilerin mesleki dersler için gerekli araç-gereç yetersizliğinden dolayı uygulama imkânı bulamaması gösterilmiştir (Gürdoğan ve Atabey, 2012; illban ve Köstekli, 2012; Karaman, vd., 2012; Kılıç ve Bayraktaroğlu, 2012; Pelit, vd., 2012; Zengin ve Türkseven, 2012).

Türkiye'de turizm eğitimi veren yükseköğretim düzeyindeki eğitim kurumlarında ve bunlara bağlı birimlerde devamlı bir artış görülmektedir. Lisans düzeyinde turizm eğitimi veren üniversite sayısı 2002 yılında 21 (Ural ve Pelit, 2002) iken, 2017 yılında 51'ye ulaşmıştır (Yayla vd., 2017: 50). Ancak konuya ilişkin yapılan çalıştaylarda verilen eğitime ilişkin birtakım sorunlar olduğu tespit edilmiştir. Bu sebeple öncelikli olarak uygulamalı eğitimin büyük önem arz ettiği lisans düzeyinde turizm eğitiminde öğrencilere uygulama alanlarının tahsis edilmesi gerekmektedir. Kurulacak konukevi, misafirhane gibi tesislerde öğrenciler görevlendirilerek sektör tecrübesi olan ve uygulama yaptırabilecek öğretim elemanlarının desteği ile öğrencilerin staja gitmeden önce de sektöre dair uygulamalı bilgi sahibi olması sağlanabilir.

\section{Uygulamalı Mutfak Dersleri}

Temelde kuramsal ve uygulamalı eğitim olmak üzere iki kısma ayrılan mesleki turizm eğitimi, uygulama olmadan eksik kalacaktır. Çünkü sadece teorik bilgi ile hizmete dayalı bir sektörde çalışmak büyük sıkıntılara yol açacaktır. Keza özellikle lisans düzeyinde aldığı turizm eğitiminde herhangi bir uygulama yapma imkânı olmayan öğrenciler sektörde önemli ölçüde zorlanmakta ve öğrencilerin uzun vadede işinden uzaklaştığı gözlenmektedir. Ortaöğretimde amaç daha çok ara eleman yetiştirmek olduğu için öğrenciler daha geniş bir uygulama imkânı bulurken, lisans aşamasındaki öğrencilerin uygulama alanlarının daha kısıtlı olduğu söylenebilir. Bu sebeple Turizm İşletmeciliği ve Otelcilik Yüksekokulları ile Turizm Fakülteleri'nin öğrencilerin uygulamaya yönelik faaliyetlerini arttırabilmek adına gerekli altyapıyı oluşturmuş olması gerekmektedir. Altyapıdan kasıt, sadece fiziksel birtakım koşulların yerine getirilmesi değil, aynı zamanda müfredatlarda uygulamalı derslerin tanımlanması ve bu dersleri yürütebilecek yeterli donanıma sahip öğretim elemanlarının istihdam edilmesidir. Bu sayede öğrenciler sektörde karşılaşabilecekleri durumlara karşı okulda bir ön hazırlığa tabi tutulabilecektir. Bu uygulama alanları çeşitli simülasyon sınıfları şeklinde olabileceği gibi doğrudan işi görebileceği ya da deneyimleyebileceği fiziksel mekanlar da kurulabilir.

Yapılmış birçok çalışmada dünyanın farklı ülkelerinde mesleki turizm eğitimi veren yükseköğretim kurumlarının eğitim programları ya da ders müfredatları ve bunların yeterlilikleri tartışılmıştır. Tayvan (Chang ve Hsu, 2010; Chang, Chung, Hsu, 2012), Avustralya (Wang, Ayres, Huyton, 2011; Dredge vd., 2013), Ürdün (Hawkins, Ruddy, Ardah, 2012), İspanya (López-Bonilla \& LópezBonilla, 2014), Çin (Yang, Song, 2011; Li ve Li, 2013), Hindistan (Dahiya, 2013), Filipinler (Solis, 2013) bu ülkelerden bazılarıdır. Türkiye'de de araştırmacılar tarafından (Yeşiltaş, Öztürk, Hemmington, 2010; Pirnar, 2014) bu yönde birtakım akademik çalışmalar yürütülmüştür. Bununla birlikte bazı araştırmalarda Avustralya ve Çin (Wang, Huyton, Gao, Ayres, 2010), Tayland ve Malezya (Thitthongkam, Walsh, 2010), Ingiltere ve Tayvan (Teng, Horng, Baum, 2013) gibi ikili karşılaştırmalar ile birlikte Avustralya, Çin ve Ingiltere (Airey, Tribe, Benckendorff, Xiao, 2015) gibi üç ülkenin mesleki turizm eğitimi programlarının karşılaştırıldığı görülmektedir. Buradan çıkarımla turizm sektörüne yön vereceği varsayılan turizm öğrencilerinin zorunlu tutulduğu müfredatların ne kadar hassas bir konu olduğu anlaşılmaktadır. Günümüzde hala bu tarz araştırmalar yapılmakta, ders programları her geçen yıl turizm sektörü ihtiyacı ya da yeni turistik talepler göz önüne alınarak revize edilmektedir. Bunun dışında öğrencilerin müfredatları, işlenen dersleri nasıl bulduğuna ya da genel anlamda konu ile ilgili düşüncelerine değinen araştırmalar da bulunmaktadır (Eurico, Silva, Valle, 2015; Gross, Manoharan, 2016).

Dünya üzerinde birçok üniversitede mesleki turizm eğitimi programlarına uygulamalı dersler dâhil edilmektedir. Bu dersler içerisinde öğrencilerin özellikle mutfak departmanını daha yakından tanımasına imkân verecek çok çeşitli uygulamalı mutfak dersleri bulunmaktadır. Literatür tarandığında daha çok yiyecek içecek işletmeciliği ya da gastronomi bölümünde okuyan öğrencilerin mutfak becerilerini konu alan araştırmalar olduğu gözlenmektedir (Ko, 2010a; Edens, 2011). Ancak bununla birlikte turizm işletmeciliği öğrencilerinin mesleki mutfak yeterliliklerinin ölçüldüğü (Ko, 2010b), öğrenciler ile mutfak dersi veren öğretmenlerin uygulamalı mutfak eğitimine bakış açılarının tespit edildiği (Kang, 2011) çeşitli araştırmalar mevcuttur. Bunlar dışında mutfak derslerine ilişkin öğrencilerin öğrenme memnuniyetleri (Ko, Chung, 2015), etkili öğrenme, mesleki yeterlilik ve

| Kastamonu Eğitim Dergisi, 2020, Vol. 28, No. 4| 
öğrenme performansları arasındaki ilişki (Ko, 2012) ya da bu dersi veren öğretmenlerin eğitim kalitesine (Ko, Chiu, 2011) ilişkin araştırmalar da göze çarpmaktadır.

\section{YÖNTEM}

\section{Araştırmanın Amacı}

Türkiye'de turizm öğrencileri ortaöğretim seviyesindeki kadar çok olmasa da yükseköğretim düzeyinde teorik dersler yanı sıra uygulamalı birtakım dersler almaktadır. Bunlar içerisinde mutfak hizmetleri, uluslararası mutfaklar ya da dünya mutfakları, Türk mutfağı gibi mutfak eğitimine yönelik dersler de bulunmaktadır. Bu dersler, öğrencileri sektöre hazırlaması açısından büyük önem taşımaktadır. Çünkü özellikle etkin ve verimli bir öğrenme süreci sonunda öğrencinin yeterli bilgiye sahip olabileceği ve sektöre girişte acemilik yaşamayacağı varsayılmaktadır. Ancak bazı üniversite öğrencilerinin bu tarz uygulamalı derslere pek sıcak bakmadığı, yazarlar tarafından yıllar boyu verilen uygulamalı mutfak dersleri esnasında gözlenmiştir. Bununla birlikte öğrencilerin dersi almadan önce önyargı ile yaklaştıkları ancak dönem sonunda dersten oldukça memnun kaldıkları gözlenen diğer davranışlardandır. Bu sebeple araştırmada öncelikle öğrencilerin uygulamalı mutfak derslerine ilişkin düşüncelerini tespit etmek amaçlanmıştır. Araştırmanın ilk ana amacı bu olmakla birlikte, bir de alt amaç bulunmaktadır.

- Uygulamalı mutfak dersi alan ve henüz almamış olan öğrencilerin uygulamalı mutfak eğitimine ilişkin düşünceleri arasında herhangi bir farklılık var mıdır?

Araştırmanın bir diğer ana amacı ise öğrencilerin ders sonunda çıktı olarak ürettikleri ürünlerin misafirler tarafından beğenilip beğenilmeme durumlarıdır. Bu durumun öğrencilerin etkin bir öğrenme gerçekleştirdiğini kanıtlayabilecek önemli bir olgu olduğu varsayılabilir. Bununla birlikte bu amaca binaen bir alt amaç belirlenmiştir.

- Uygulamalı mutfak dersi kapsamında sunulan hizmet ile normal zamanda sunulan hizmet arasında müşteri memnuniyeti açısından herhangi bir farklılık var mıdır?

$\mathrm{Bu}$ ana ve alt amaçlar ile öğrencilerin derse ilişkin düşünceleri objektif bir şekilde değerlendirilebilecek, öğrencilerin dersi almadan ve aldıktan sonra derse ilişkin bakış açılarında bir değişiklik olup olmadığı tespit edilebilecektir. Bununla birlikte ders kapsamında ürettikleri ürünlerin ne kadar başarılı olduğu müşteri yanıtları doğrultusunda ölçülebilecek ve normal zamanda çıkarılan yemek ile ders kapsamında üretilen yemek arasında müşteri memnuniyeti açısından herhangi bir farklılık olup olmadığı anlaşılabilecektir. Bu sayede uygulamalı mutfak derslerinin ne kadar başarılı olduğu ya da olmadığı hem öğrenci hem de müşteri gözünden değerlendirilerek literatüre katkı sağlanacaktır.

\section{Araştırmanın Evreni}

Araştırma hem öğrenci hem de restoran müşterilerini kapsadığı için iki evren ve örneklem bulunmaktadır. Öğrencilerden oluşan evren Kastamonu Üniversitesi Turizm Fakültesi bünyesinde bulunan Turizm İşletmeciliği bölümü müfredatında yer alan Uluslararası Mutfaklar dersini alan öğrencilerdir. Aktif olarak derse devam eden tüm öğrencilere ulaşılarak tam sayıma gidilmiştir.

Müşterileri kapsayan evren Kastamonu Üniversitesi Turizm Fakültesi bünyesinde faaliyet gösteren konukevine öğle yemeği için gelen misafirlerdir. Konukevinde hafta içi her gün ortalama 30 kişilik yemek hizmeti sunulmaktadır. Araştırma kapsamında evrenin tamamına ulaşılması planlanmıştır. Bir sömestr boyunca öğle yemeğine gelen tüm misafirlere tamamen gönüllülük esasına dayalı olarak anket formunu doldurmaları rica edilmiştir.

\section{Araştırmanın Kısıtları}

Araştırmanın ilk kısıtı 2017-2018 güz yarıyılı içerisinde gerçekleştirilmesidir. Bir diğer kısıt ise araştırmanın sadece uygulamalı mutfak eğitimini temel alan bir araştırma olmasıdır. O dönemde fakültede okutulan tek uygulamalı mutfak dersi Uluslararası Mutfaklar dersi olduğu için, araştırma bu dersi alan öğrenciler ile kısıtlanmıştır.

\section{Veri Toplama Yöntemi}

Araştırmada nicel bir tasarım benimsenmiş ve anket tekniğinden faydalanılmıştır. Öğrencilerin uygulamalı mutfak derslerine ilişkin düşüncelerini tespit edebilmek amacıyla Çemrek \& Yılmaz (2010) tarafından geliştirilen 25 ifadeden oluşan anket formu kullanılmıştır. Bu formun tercih edilmesinin sebebi Türkiye'deki mesleki turizm eğitimi göz önüne alınarak oluşturulmuş olmasıdır. Formda ayrıca öğrencilerin cinsiyet, öğrenim durumu ve genel not ortalamasına dair demografik değişkenlere de yer verilmiştir.

Müşteri memnuniyetini ölçmek amacıyla yiyecek kalitesi, hizmet kalitesi ve müşteri memnuniyeti boyutlarını içeren toplam 16 ifadeden oluşan bir anket formu hazırlanmıştır. Yiyecek kalitesi ve hizmet kalitesi boyutlarına ilişkin 13 ifade Yüksel \& Yüksel (2002)'in çalışmasından esinlenilerek araştırmaya uyarlanmıştır. Müşteri memnuniyeti boyu-tunda yer alan üç ifade ise yazarlar tarafından oluşturulmuştur. Bu formda araştırma açısından gereklilik arz etmediği için müşterilere ilişkin herhangi bir demografik değişkene yer verilmemiştir. İki formda da 5'li Likert ölçeğinden (1 = Tamamen katılmıyorum; 5 = Tamamen katılıorum) faydalanılmıştır.

Her iki formda, iki farklı aşama kullanılmıştır. Öğrenciler için hazırlanan formlar dönem başında öğrenciler ilk derse girmeden önce uygulanmış ve toplamda 85 anket formu elde edilmiştir. Aynı anket formu dönem sonunda (dört ay sonra) aynı öğrencilere final sınavından sonra tekrar uygulanarak, 85 anket formu toplanmıştır. Öncesi ve sonrası olmak üzere toplamda 170 adet öğrenci anketi elde edilmiştir. 
Öğrenciler ders kapsamında dönem boyunca haftanın üç günü onar kişilik gruplar halinde çeşitli ülke mutfaklarına yönelik uygulama yapmıştır. Ülke mutfakları konusunda öğrenciler kısıtlanmamış, hangi mutfağa ilişkin uygulama yapacaklarına kendileri karar vermiştir. Uygulamalar fakülte bünyesinde bulunan konukevinin mutfağında gerçekleştirilmiş ve öğle yemeği için konukevine gelen misafirlere yine öğrenciler tarafından sunulmuştur. Haftanın iki günü ise konukevi mutfağı çalışanları tarafından rutin öğle yemeği hizmeti verilmiştir. Müşteri memnuniyetini ölçmeye yönelik hazırlanan anket formları haftanın her günü gelen misafirlere uygulanmış, uygulama zamanında alınan yanıtlar ile normal zamanda alınan yanıtlar ayrıştırılmıştır. Uygulama zamanı misafirler tarafından toplam 265 anket formu doldurulmuş, ancak hatalı ya da eksik doldurulan anketler çıkarıldıktan sonra 259 anket formu değerlendirmeye alınmıştır. Normal zamanda ise toplam 236 anket formu değerlendirmeye alınmıştır. Toplamda 495 adet müşteri anketi elde edilmiştir.

\section{Ön Çalışma}

Araştırma için kesin anket formu hazırlanıp veri toplamaya geçilmeden önce araştırma örneğini temsil edecek şekilde seçilen 20 öğrenci ve 20 müşteri ile pilot çalışma yapılmıştır. Her iki gruba da ilgili formlar gösterilerek, ölçeklerin uygunluğu ve anlaşıırlı̆̆ını belirtmeleri istenmiştir. Yanıtlayıcı yorumlarına bakılarak bazı ifadeler değiştirilmiş ve anket formuna son hali verilmiştir. Öğrenciler ile yapılan pilot çalışmanın güvenilirliği ,834 iken, müşteri memnuniyeti ölçeğinin güvenilirliği ,960 çıkmıştır.

\section{BULGULAR}

Öğrencilerin 54'ü kız, 31'i erkek olup, normal öğretimde okuyan öğrenci sayısı 50, ikinci öğretimlerin sayısı 35'dir. Öğrencilerin genel not ortalamaları değerlendirildiğinde on öğrencinin ortalamasının 1.75'den az olduğu tespit edilmiştir. 1.75 ile 2.50 arasında ortalamaya sahip olan öğrenci sayısı 38 olup, genelin \%22,4’ünü oluşturmaktadır. Bunun ardından ortalamalar içerisinde en çok işaretlenen seçenek \%19,4 ile 2.51 ile 3.25 arası olmuştur. Yani öğrencilerin önemli bir çoğunluğunun ortalaması 1.75 ile 3.25 arasındadır. Bunlara ek olarak ortalaması 3.26 ile 4.00 arasında değişen akademik başarısı yüksek öğrenci sayısı 4 'tür.

\section{Uygulamalı Mutfak Dersi Ölçeğine ilişskin Faktör Analizi}

Öğrencilerin uygulamalı mutfak derslerine ilişkin düşüncelerini tespit edebilmek amacıyla Çemrek \& Yılmaz (2010) tarafından geliştirilen ölçeğe açımlayıcı faktör analizi uygulanmıştır. Verilerin dağılımı incelenmiş olup, çarpıklık ve basıklık katsayıları değerlendirilmiştir. Bu değerlerin -1.5 ile +1.5 arasında olması gerektiği ifade edilmektedir (Tabachnick ve Fidell, 2012). Değerlerin belirtilen aralıkta olması sebebiyle verilerin normal dağılım gösterdiği kabul edilmiştir. Analizlerde açıklayıcı model olarak temel bileşenler analizi ve varimax döndürme seçenekleri kullanılmıştır.

Açımlayıcı faktör analizi uygulanmadan önce örneklem büyüklüğünün faktör analizine uygunluğunu gösteren KMO değeri hesaplanmış ve 0,878 olarak bulunmuştur. Bulunan bu değer, örneklem büyüklüğünün yapılacak faktör analizi için yeterli olduğunu göstermektedir. Verilerin faktör analizine uygunluğunu tespit eden Bartlett's Sphericity testi anlamlı $(p<0.000)$ bulunmuştur. Ölçekte yer alan değişkenlerin cronbach alpha değerlerine ve değişkenler arasındaki ilişki kat sayılarına bakılmıştır. Bu aşamada düşük cronbach alpha değerine ve ilişki katsayısına sahip bir madde analizden çıkarılmıştır. 24 maddeye uygulanan faktör analizi sonucu faktör yükü .30'un altında kalan iki madde analizden çıkarılmıştır. Faktör analizinin sonuçlarına ilişkin değerler Tablo 1'de sunulmuştur.

Tablo 1'de görüldüğü üzere, faktör analizi sonucunda ölçek 22 madde ve dört boyuttan oluşmuştur. Faktörlerdeki maddelerin ifade ettiği anlamlar doğrultusunda Faktör 1: Verimlilik, Faktör 2: Gelişime katkı, Faktör 3: Adaptasyon, Faktör 4: Gereklilik olarak isimlendirilmiştir. Genel olarak dört faktörün varyansı toplam açıklama oranı ise \%61,818 olarak elde edilmiştir. Faktörlerin varyansı açıklama oranlarına bakıldığında, verimlilik faktörünün daha yüksek bir açıklama oranına sahip olduğu görülmektedir.

Tablo 1. Öğrencilerin uygulamalı mutfak dersine ilişkin düşüncelerini tespit etmeye yönelik ölçeğin açımlayıcı faktör analizi

\begin{tabular}{|c|c|c|c|c|}
\hline & $\begin{array}{l}\text { Faktör } \\
\text { Yükü }\end{array}$ & $\begin{array}{c}\text { Öz } \\
\text { Değer }\end{array}$ & $\begin{array}{c}\text { Açık. } \\
\text { Varyans }\end{array}$ & $\begin{array}{c}\text { Alfa } \\
\text { Değeri }\end{array}$ \\
\hline 1-Verimlilik & & 5,420 & 24,637 & 0,912 \\
\hline Dersi veren öğretim elemanları destekleyici ve cesaretlendiricidir. & 0,798 & & & \\
\hline Uyg. mutfak derslerinde öğrendiklerimi iş hayatıma aktarabilmekteyim. & 0,789 & & & \\
\hline Uyg. mutfak derslerinde öğrendiklerimi günlük hayata aktarabilmekteyim. & 0,749 & & & \\
\hline $\begin{array}{l}\text { Uygulamalı mutfak dersleri sayesinde mutfakta şeflerimin karşısında heyecanımı } \\
\text { yenebilirim/yenebileceğim. }\end{array}$ & 0,734 & & & \\
\hline $\begin{array}{l}\text { Uygulamalı mutfak dersleri sayesinde turizm sektöründe mutfaktaki iş aşamalarının, } \\
\text { mutfak faaliyetlerinin nasıl yürüdüğünü anlayabiliyorum. }\end{array}$ & 0,709 & & & \\
\hline $\begin{array}{l}\text { Sektörde mutfak departmanında işe başladığımda işlere kolaylıkla uyum } \\
\text { sağlayabileceğimi düşünüyorum. }\end{array}$ & 0,676 & & & \\
\hline $\begin{array}{l}\text { Uygulamalı mutfak dersleri sayesinde kalite, hijyen ve maliyet konularında geliştiğimi } \\
\text { düşünüyorum. }\end{array}$ & 0,675 & & & \\
\hline Uygulamalı mutfak dersleri ile hayattaki bazı becerilerimin geliştiğine inanıyorum. & 0,673 & & & \\
\hline Dersi veren öğretim elemanları mutfak konusunda tecrübelidir. & 0,655 & & & \\
\hline 2-Gelişime katkı & & 4,068 & 18,490 & 0,888 \\
\hline
\end{tabular}

| Kastamonu Eğitim Dergisi, 2020, Vol. 28, No. 4| 
Uygulamalı mutfak dersleri sayesinde mesleğimi sevdim.

Faktör Öz $\quad$ Açık. Alfa

Yükü Değer Varyans Değeri

Uygulamalı mutfak dersleri sayesinde mutfak konusundaki bazı becerilerim de gelişmektedir.

0,770

Uygulamalı mutfak dersleri sayesinde geliştiğimi düşünüyorum.

0,747

0,740

0,701

Uygulamalı mutfak derslerinin gerekli olduğunu düşünüyorum.

0,685

Uygulamalı mutfak dersleri sayesinde mutfakta iş deneyimi kazandığıma inanıyorum. $\quad 0,641$

3-Adaptasyon

(R)

Uygulamalı mutfak derslerine girmemenin yollarını arıyorum. (R)

0,725

$2,445 \quad 11,112 \quad 0,666$

0,724

Uygulamalı mutfak derslerindeki gözlemlerden (ya da hocalarımın gözlemlerinden) sıkılıyorum. (R)

Uygulamalı mutfak dersleri yüzünden mesleğimden soğudum. (R)

0,706

4-Gereklilik

Uygulamalı mutfak dersleri gereksizdir. (R)

0,580

Uygulamalı mutfak derslerinde öğrendiğim bilgiler sektörde (ya da iş hayatında) işime yaramayacak. $(\mathrm{R})$

Uygulamalı mutfak dersleri için belirlenen süreler çok uzun. (R)

0,723

1,667

7,579

0,625

0,525

Açıklanan Varyans: 61,818 KMO: 0,878 Bartlett Testi, $p<, 000$

Ölçeği oluşturan dört faktörün güvenilirlikleri değerlendirildiğinde, verimlilik faktörünün 0,912 , gelişime katkı faktörünün 0,888 , adaptasyon faktörünün 0,666 ve gereklilik faktörünün 0,601 olduğu görülmektedir. Ölçeğe ilişkin cronbach's alpha değerlerinin sosyal bilim araştırmaları için kabul edilebilir sınırda olduğu söylenebilir (Hair, Black, Babin \& Anderson, 2010: 92).

\section{Öğrencilerin Ders Öncesi ve Sonrası Düşüncelerinin Tespit Edilmesi}

Turizm işletmeciliği öğrencilerinin uygulamalı mutfak dersini almadan önce ve aldıktan sonraki düşüncelerinde herhangi bir farklılık olup olmadığııı test etmek amacıyla bağımlı iki örneklem t-testi uygulanmıştır.

Tablo 2. Öğrencilerin ders öncesi ve sonrası düşüncelerine ilişkin $t$ testi

\begin{tabular}{|c|c|c|c|c|c|}
\hline Faktörler & Gruplar & $\mathrm{N}$ & $\bar{X}$ & Std. Sapma & $\mathrm{p}$ \\
\hline \multirow{2}{*}{ Verimlilik } & Ön test & 85 & 3,22 & 0,964 & \multirow{2}{*}{$0,000 *$} \\
\hline & Son test & 85 & 3,83 & 0,751 & \\
\hline \multirow{2}{*}{ Gelişime katkı } & Ön test & 85 & 3,09 & 1,002 & \multirow{2}{*}{$0,000 *$} \\
\hline & Son test & 85 & 3,92 & 0,769 & \\
\hline \multirow{2}{*}{ Adaptasyon } & Ön test & 85 & 3,25 & 0,853 & \multirow{2}{*}{$0,001 *$} \\
\hline & Son test & 85 & 3,68 & 0,825 & \\
\hline \multirow{2}{*}{ Gereklilik } & Ön test & 85 & 3,02 & 0,975 & \multirow{2}{*}{$0,000 *$} \\
\hline & Son test & 85 & 3,79 & 0,790 & \\
\hline
\end{tabular}

Öğrencilerin uygulamadan önceki ve sonraki düşüncelerine ilişkin faktör ortalamaları arasında istatistiksel olarak anlamlı farklılıklar tespit edilmiştir $(p<0,001)$. Öğrencilerin tüm faktörler açısından ders öncesinde genel bir kararsızlık yaşadığı ancak ders sonrası düşünceleri tekrar sorulduğunda ortalamaların yükselerek olumluya döndüğü tespit edilmiştir.

\section{Restoran Müşteri Memnuniyeti Ölçeğinin Faktör Analizi}

Öğrencilerin uygulamalı mutfak dersleri kapsamında sunduğu hizmete yönelik müşteri memnuniyetini tespit etmek amacıyla hazırlanan anket formuna açımlayıcı faktör analizi uygulanmışıı. Verilerin normal dağılım gösterdiği gözlenmiştir. Analizlerde açıklayıcı model olarak temel bileşenler analizi ve varimax döndürme seçenekleri kullanılmıştır. KMO değeri 0,914 olarak hesaplanmış ve Bartlett's Sphericity testi anlamlı $(p<0.000)$ bulunmuştur. Ölçekte yer alan değişkenlerin cronbach alpha değerlerine ve değişkenler arasındaki ilişki kat sayılarına bakıımışıı. Bu aşamada düşük cronbach alpha değerine ve ilişki katsayısına sahip bir madde analizden çıkarılmıştır. Faktör analizinin sonuçlarına ilişkin değerler Tablo 3'de sunulmuştur. Faktör analizi sonucunda ölçek 15 madde ve dört boyuttan oluşmuştur. Faktörlerdeki maddelerin ifade ettiği anlamlar doğrultusunda Faktör 1: Yiyecek Kalitesi, Faktör 2: Personel Kalitesi, Faktör 3: Hizmet Kalitesi, Faktör 4: Genel Memnuniyet olarak isimlendirilmiştir. Genel olarak dört faktörün varyansı toplam açıklama oranı ise $\% 76,331$ 'dir. Faktörlerin varyansı açıklama oranlarına bakıldığında, yiyecek kalitesi faktörünün daha yüksek bir açıklama oranına sahip olduğu görülmektedir. Ölçeği oluşturan faktörlerin güvenilirlikleri ise $0,80^{\prime}$ in üzerinde olması sebebiyle yüksek kabul edilmektedir. 
Tablo 3. Restoran müşteri memnuniyeti ölçeğine ilişkin faktör analizi sonuçları

\begin{tabular}{|c|c|c|c|c|}
\hline & $\begin{array}{l}\text { Faktör } \\
\text { Yükü }\end{array}$ & $\begin{array}{c}\text { Öz } \\
\text { Değer }\end{array}$ & $\begin{array}{c}\text { Açık. } \\
\text { Varyans }\end{array}$ & $\begin{array}{c}\text { Alfa } \\
\text { Değeri }\end{array}$ \\
\hline 1-Yiyecek Kalitesi & & 4,576 & 30,507 & 0,905 \\
\hline Restoranda sunulan yiyecekler yüksek kaliteli & 0,848 & & & \\
\hline ... taze ürünler ile hazırlanmış & 0,811 & & & \\
\hline ... lezzetli & 0,786 & & & \\
\hline ... sağlıklı ve besleyici & 0,777 & & & \\
\hline ... görünüş itibariyle çekici & 0,772 & & & \\
\hline ... temiz, hijyenik bir ortamda hazırlanmış & 0,658 & & & \\
\hline 2- Personel Kalitesi & & 3,044 & 20,291 & 0,890 \\
\hline Çalışan personel görünüşü temiz, düzgün ve bakımlıdır. & 0,858 & & & \\
\hline Çalışan personel işinde yetkin. & 0,856 & & & \\
\hline Çalışan personel yardımsever. & 0,830 & & & \\
\hline 3-Hizmet Kalitesi & & 2,141 & 14,272 & 0,830 \\
\hline Restoranda standart bir hizmet sunuluyor. & 0,864 & & & \\
\hline Restoranda yiyecek hazırlık alanları görülebilir. & 0,778 & & & \\
\hline Restoranda özenli bir hizmet sunuluyor. & 0,567 & & & \\
\hline 4-Genel Memnuniyet & & 1,689 & 11,262 & 0,833 \\
\hline Genel olarak servis kalitesinden memnunum. & 0,763 & & & \\
\hline Genel olarak personelden memnunum. & 0,693 & & & \\
\hline Genel olarak yiyecek kalitesinden memnunum. & 0,512 & & & \\
\hline
\end{tabular}

Açıklanan Varyans: 76,331 KMO: 0,914 Bartlett Testi, $\mathrm{p}<, 000$

\section{Restoran Müşteri Memnuniyeti Farklılığı}

Öğrencilerin dersi ne kadar verimli geçirdiğini yani uygulamalı mutfak dersinin etkinliğini tespit edebilmek amacıyla ders sonucu elde edilen çıktılara yönelik müşteri memnuniyeti ölçülmüştür. Öğrencilerin ders kapsamında sunduğu hizmete yönelik müşteri memnuniyeti ile normal zamanda sunulan hizmet arasındaki memnuniyette herhangi bir farklılık olup olmadığı analiz edilmiştir. Bu sayede öğrencilerin normal zamanlı restoran hizmeti ile rekabet edebilecek yetkinliğe ulaşıp ulaşmadığı gözlenmiştir

Tablo 4. Öğrenci ve personelin sunduğu hizmet ile müşteri memnuniyeti arasındaki farklılık

\begin{tabular}{|c|c|c|c|c|c|c|}
\hline & & $\mathrm{N}$ & $\overline{\bar{X}}$ & Std. Deviation & $t$ & $p$ \\
\hline Yiyecek & Öğrenci & 259 & 4,28 & 0,626 & \multirow{2}{*}{1,606} & \multirow{2}{*}{0,109} \\
\hline Kalitesi & Personel & 236 & 4,19 & 0,662 & & \\
\hline Personel & Öğrenci & 259 & 4,53 & 0,592 & \multirow{2}{*}{2,227} & \multirow{2}{*}{$0,026^{*}$} \\
\hline Kalitesi & Personel & 236 & 4,40 & 0,653 & & \\
\hline Hizmet & Öğrenci & 259 & 4,36 & 0,561 & \multirow{2}{*}{3,640} & \multirow{2}{*}{$0,000 * *$} \\
\hline Kalitesi & Personel & 236 & 4,15 & 0,673 & & \\
\hline Genel & Öğrenci & 259 & 4,46 & 0,526 & \multirow{2}{*}{2,090} & \multirow{2}{*}{$0,037 *$} \\
\hline Memnuniyet & Personel & 236 & 4,36 & 0,581 & & \\
\hline
\end{tabular}

$$
* p<0,05 \quad * * p<0,001
$$

Yiyecek kalitesi açısından normal zamanda sunulan hizmet ile uygulamalı mutfak dersi kapsamında sunulan hizmete yönelik müşteri memnuniyeti arasında herhangi bir farklılık tespit edilememiştir ( $t=1,606, p=0,109)$. Bu sonuç öğrencilerin yaptığı yemeklerin rutin çıkarılan yemekler ile aynı kaliteye sahip olduğunu göstermektedir. Restorana gelen müşteriler yemeklerin kalitesi, lezzeti, besleyiciliği, çekiciliği ve hazırlanışı açısından daha önce aldıkları hizmete benzer bir hizmet aldıklarını hissetmiş ve aynı memnuniyeti yaşamıştır.

Mutfak personelinin sunduğu hizmet ile ders kapsamında sunulan hizmete yönelik müşteri memnuniyetinde personel kalitesi açısından anlamlı farklılık tespit edilmiştir $(t=2,227, p=0,026)$. Ortalamalar arası farklılığa bakıldığında, öğrencilerin ders günündeki personel hizmetine yönelik müşteri memnuniyeti $(4,53)$ iken, normal zamanda verilen personel hizmetindeki memnuniyet $(4,40)$ daha düşük bir ortalamaya sahiptir. Yani restoran müşterileri ders kapsamında sunum yapan öğrencilerin görünüş, işi bilme ve yardımseverliğinden daha fazla memnun kalmışlardır.

Mutfak personelinin sunduğu hizmet ile öğrencilerin sunduğu hizmetin kalitesi açısından da müşterilerin memnuniyetlerinin farklılaştığı görülmüştür ( $t=3,640, p=0,000)$. Ortalamalar arası farklılık değerlendirildiğinde, personelin hizmet kalitesine yönelik müşteri memnuniyeti 4,15 ortalamaya sahip iken, öğrencilerin hizmet kalitesine yönelik memnuniyet 4,36 ile daha yüksek bir ortalamaya sahiptir. Restoranda sunulan hizmete ilişkin müşterilerin genel memnuniyetleri incelendiğinde, ortalamalar arası farklılıklar tespit edilmiştir ( $t=2,090, p=0,037)$. Müşterilerin öğrencilerin verdiği hizmetten daha memnun kaldığı anlaşılmıştır.

\section{SONUÇ VE ÖNERILER}

Bu araştırmada, Turizm İşletmeciliği öğrencilerinin "Uluslararası Mutfaklar” dersi kapsamında verilen uygulamalı mutfak eğitimine yönelik düşünceleri iki aşamalı olarak (ders öncesi ve sonrası) tespit edilmiştir. Bununla birlikte öğrencilerin bu ders 
kapsamında ürettiği ve sunduğu yemeklere yani hizmete yönelik müşteri memnuniyeti ile normal zamanda sunulan hizmet arasındaki memnuniyette herhangi bir farklılık olup olmadığı analiz edilmiştir.

Öğrencilerin derse girmeden önce derse ilişkin genel bir kararsızlık yaşadığı ancak ders sonrası düşünceleri tekrar sorulduğunda olumluya dönük bir gelişme gösterdiği tespit edilmiştir. Genellikle Türk eğitim sisteminde özellikle turizm fakültesi öğrencilerinin uygulamalı eğitimlere pek sıcak bakmadığı tecrübeler ışığında söylenebilir. Ancak bu araştırma, öğrencilere uygulamalı eğitimin önemi anlatılır, yeteri kadar uygulama imkânı sağlanırsa öğrencilerin bakış açılarının iyi yönde değişebileceğini göstermektedir. Türk eğitim sisteminde her ne kadar ilk derste, dersin öneminin anlatılması gerektiği bilinen bir gerçek olsa da, genellikle atlanmakta ve doğrudan derse geçilmektedir. Halbuki öğrenciler yeteri kadar bilgi sahibi olurlarsa önlerini daha iyi görebilmekte ve daha sağduyulu yaklaşabilmektedir. Bununla birlik-te öğrencilere uygulamalı dersleri sevdirecek birtakım faaliyetler yürütülebilir. Çünkü öğrencilerin uygulamalı dersler ile ilgili olumlu görüşlerinin daha faydalı bir öğrenme süreci yaratacağı söylenebilir. Bu durum da özellikle sektöre girdiklerinde kendilerini daha güvende hissetmelerini sağlayacak bilgi birikimine sahip olmaları demektir.

Ortalamalar arası farklılıklar değerlendirildiğinde en büyük farklılığın, öğrencilerin uygulamalı mutfak derslerinin gerekliliğine ilişkin düşüncelerinde gerçekleştiği görülmüştür. Yani öğrenciler dersi aldıktan sonra dersin daha gerekli olduğunu ve ders sürelerinin daha uzun olması gerektiğini ifade etmiştir. Kang (2011: 475)'da yaptığı araştırmada benzer şekilde öğrencilerin öğrenme taleplerinin yüksek olduğunu ve daha fazla uygulamanın talep edildiğini tespit etmiştir. Bu araştırmada öğrencilerin en fazla önemsediği konulardan biri de dersi veren öğretim elemanlarının destekleyici ve cesaretlendirici olmasıdır. Kang (2011: 475)'da çalışmasında öğretmenlerin dersin işlenişi açısından oldukça önemli bir yere sahip olduğunu ve mesleki yeterlilikleri açısından daha fazla eğitim desteğinin gerektiğini belirtmiştir.

Öğrencilerin sunduğu hizmete yönelik müşteri memnuniyetinde, yaptıkları yemeğin kalitesi açısından normal zamanlı hizmet ile farklılaşmadıkları tespit edilmiştir. Bu durum aslında sektör tecrübesi olan mutfak personelleri kadar iyi bir yemek çıkarabildiklerini göstermesi açısından oldukça önemlidir. Gereken eğitim verildiğinde ve uygulama imkânı sunulduğunda öğrencilerin konuyu ne kadar ciddiye aldığı ve gereken hassasiyeti gösterdiği gözlenmiştir. Bu durum çıkardıkları yemeğin kalitesine de yansımış ve müşteri memnuniyetinde herhangi bir farklılık yaşanmamasına sebebiyet vermiştir. Bununla birlikte diğer üç boyut açısından personel hizmeti ile öğrencilerin sunduğu hizmette müşteri memnuniyeti farklılık göstermiştir. Ancak bu farklılıkların tamamı öğrencilerin lehine olmuş ve onlara yönelik müşteri memnuniyetinin daha yüksek ortalamalara sahip olduğu görülmüştür. Genel olarak müşteriler normal zamanlı hizmete kıyasla öğrencilerin sunduğu hizmetten daha fazla memnun kalmıştır. Bu durum sebebiyle öğrencilerin derse ilişkin olumlu düşüncelerinin müşteriye de yansıdığı ve aslında uygulamalı eğitimi başarı ile tamamladıkları söylenebilir. Bu durum aslında öğrencilerin mesleki mutfak yeterliliklerini de ortaya koymaktadır. Ko (2010b)'da farklı bir yol izleyerek turizm işletmeciliği öğrencilerinin mesleki mutfak yeterliliklerini ölçmüştür. Faktör analizi sonucu temel mutfak bilgisi, mutfak inovasyonu, temel mutfak becerileri, mutfak yönetimi ve mutfak tutumu olmak üzere beş faktör belirlemiştir. Erkeklerin ve kıdemli öğrencilerin mutfak yönetiminde önemli derecede daha yüksek puanlar aldığı görülmüştür.

$\mathrm{Bu}$ araştırmada öğrencilerin cinsiyetlerine ya da sınıflarına göre bir farklılık araştırılmadığı için bu tarz bir sonuç elde edilememiştir. Ancak gelecek araştırmalarda öğrencilerin derse ilişkin düşüncelerinin demografik özelliklerine göre farklılaşıp farklılaşmadığı analiz edilebilir.

Gelecek araştırmalarda öğrencilerin uygulamalı eğitime yönelik düşünceleri ile ürettiği yemeklere ve sunduğu hizmete yönelik müşteri memnuniyeti arasındaki ilişki istatistiki olarak sınanabilir. Türkiye’nin farklı bölgelerindeki turizm fakültesi öğrencilerinin düşünceleri karşılaştırılarak bölgelerarası farklılıklar ortaya konabilir. Bir sonraki aşamada eğitim sistemi benzer özellikler taşıyan yabancı bir ülke öğrencileri ile farklılaştığı noktalar tespit edilebilir.

Turizm fakültesi bünyesinde özellikle turizm işletmeciliği bölümlerinde okuyan öğrencilere yönelik uygulama imkanları ile okul hayatı desteklenmelidir. Aksi takdirde öğrenciler sadece teorik bilgiler ile sektöre giriş yapacak ve bu durum bocalamasına sebebiyet verecektir. Bu sebeple bazı temel uygulamalı dersler müfredatlara muhakkak eklenmelidir. Çok çeşitli ve farklı uygulama imkanlarının sunulamadığı durumlarda Kang (2001: 475)'ın da belirttiği gibi teorik eğitim sonrası, video eğitimi ya da uygulamalı gösterilere yönelik multimedya araçlarının kullanılabilir. Gereken hassasiyet gösterildiğinde öğrencilerin bu eğitimlerin önemini yadsımayacağı söylenebilir. Hatta bu sayede sektöre ısınması ve güzel geri dönüşler alınması bile mümkün olabilir.

\section{KAYNAKÇA}

Ahipaşaoğlu, S., Karaman, A. ve Sağlık, E. (2002). Turizm Sektöründe Endüstriye Dayalı Eğitim, Sorunlar ve Çözüm Önerileri: Palandöken Kış Sporları Merkezinde Bir Uygulama. Turizm Eğitimi Konferans-Workshop, 11-13 Aralık, (s. 137-143). Ankara, Turizm Bakanlığı, Turizm Eğitimi Genel Müdürlüğü.

Airey, D., Tribe, J., Benckendorff, P. ve Xiao, H. (2015). The managerial gaze: The long tail of tourism education and research. Journal of Travel Research, 54(2), 139-151. doi:10.1177/0047287514522877

Akoğlan Kozak M. (2009). Akademik Turizm Eğitimi Üzerine Bir Durum Analizi. Muğla Üniversitesi Sosyal Bilimler Enstitüsü Dergisi, 22 , 1-20. Erişim adresi: http://sobbiad.mu.edu.tr/index.php/asd/article/view/218

Aksu, M , Bucak, T . (2012). Mesleki Turizm Eğitimi. Aksaray Üniversitesi İktisadi ve İdari Bilimler Fakültesi Dergisi, 4 (2), 7-18. Erişim Adresi: http://dergipark.gov.tr/aksarayiibd/issue/22551/240990 
Arsoy, G. (1992). Örgün/Yaygın Eğitimde Durum Tespiti ve Turizm Eğitim Sistemimizin Geliştirilmesi İçin Öneriler. Turizm Eğitimi KonferansWorkshop, 9-11 Aralık, (s. 181-190). Ankara, Turizm Bakanlığı Turizm Eğitimi Genel Müdürlüğü.

Avcıkurt, C. ve Karaman, S. (2002). Lisans Eğitimi Veren Turizm Okullarının Ders Programları Karşılaştırması. Turizm Eğitimi Konferans-Workshop, 11-13 Aralık, (s. 53-65). Ankara, Turizm Bakanlığı Turizm Eğitimi Genel Müdürlüğg̈.

Boyacı, C. (1992). Üniversite Düzeyinde Turizm Eğitimi Veren Yükseköğretim Kurumlarında Öğretim Elemanı Yetiştirme Sorunları ve Çözüm Önerileri. Turizm Eğitimi Konferans-Workshop, 9-11 Aralık (s. 121-123). Ankara, Turizm Bakanlığı Turizm Eğitimi Genel Müdürlüğü.

Chang, T.-Y., ve Hsu, J.-M. (2010). Development framework for tourism and hospitality in higher vocational education in Taiwan. Journal of Hospitality, Leisure, Sports and Tourism Education, 9(1), 101-109. doi:10.3794/johlste.91.246

Chang, T.-Y., Chung, P.-H., ve Hsu, S.-S. (2012). Two-stage performance model for evaluating the managerial efficiency of higher education: Application by the Taiwanese tourism and leisure department. Journal of Hospitality, Leisure, Sport \& Tourism Education, 11(2), 168177. doi:10.1016/j.jhlste.2012.04.003

Çemrek, F. ve Yılmaz, H. (2010). Turizm ve Otel İşletmeciliği ile Aşçılık Programı Öğrencilerinin “Uygulamalı Mutfak Dersleri” Hak-kında Tutum ve Düşüncelerini Ölçmeye Yönelik Bir Uygulama, Afyon Kocatepe Üniversitesi Sosyal Bilimler Dergisi, 12(2), 203-220. Erişim adresi: http://www.acikerisim.aku.edu.tr/xmlui/handle/11630/3840\#sthash.ns9PFF2M.dpbs.

Dahiya, A. (2013). Hospitality and Tourism Education in India: In Search of Innovative Programmes. Productivity, 53(4), 358-370. Erişim adresi: https://www.academia.edu/4195022

Dredge, D., Benckendorff, P., Day, M., Gross, M. J., Walo, M., Weeks, P., ve Whitelaw, P. A. (2013). Drivers of change in tourism, hospitality, and event management education: An Australian perspective. Journal of Hospitality \& Tourism Education, 25(2), 89-102. doi:10.1080/10963758.2013.805091

Edens, D. (2011). Predictors of culinary students' satisfaction with learning. Journal of Hospitality \& Tourism Education, 23(3), 5-15. doi: 10.1080/10963758.2011.10697008

Eurico, S. T., da Silva, J. A. M., ve do Valle, P. O. (2015). A model of graduates' satisfaction and loyalty in tourism higher education: The role of employability. Journal of Hospitality, Leisure, Sport \& Tourism Education, 16, 30-42. doi:10.1016/j.jhlste.2014.07.002

Gökdeniz, A., Çeken, H. ve Erdem, B. (2002). Okul-Sektör İşbirliği Çerçevesinde Stajdan Beklentiler, Sorunlar, Çözüm Önerilerine Yönelik Bir Uygulama. Turizm Eğitimi Konferans-Workshop, 11-13 Aralık, (s. 343-367). Ankara, Turizm Bakanlığı Turizm Eğitimi Genel Müdürlüğü.

Gross, M. J., ve Manoharan, A. (2016). The balance of liberal and vocational values in hospitality higher education: Voices of gradua-tes. Journal of Hospitality \& Tourism Education, 28(1), 44-57. doi: 10.1080/10963758.2015.1127165

Gürdal, M. (2002). Türkiye'de Mesleki Turizm Eğitiminin Yapısal Analizi, Okullaşma- Eğitimin Kalitesi-Staj-İstihdam Sorunları ve Çözüm Önerileri, Turizm Eğitimi Konferans-Workshop, 11-13 Aralık 2002, (s. 391-400). Ankara Turizm Bakanlığı Turizm Eğitimi Genel Müdürlüğü.

Gürdoğan, A. ve Atabey, S. (2012). Meslek Yüksekokulu Öğrencilerinin Staj Sorunları ve Stajdan Beklentileri: Ortaca Örneği. Turizm Eğitimi Konferans-Workshop, 17-19 Ekim, (s. 234-247). Ankara, Turizm Bakanlığı Turizm Eğitimi Genel Müdürlüğü.

Hacıoğlu, Necdet (1992). Yükseköğretimde Mesleki Turizm Eğitim Geliştirme Perspektifi, Turizm Eğitimi konferans/Workshop, 9-11 Aralık 1992, Ankara (Aktaran) Hacıoğlu, Necdet., Kaşlı, Mehmet., Şahin, Seda. ve Tetik, Nuray. (2008). Türkiye'de Turizm Eğitimi, s:26, Ankara: Detay Yayıncilık.

Hair, J. F., Black, W. C., Babin, B. J. ve Anderson, R. E. (2010). Multivariate Data Analysis, Seventh Edition, New Jersey: Prentice Hall.

Hawkins, D. E., Ruddy, J., ve Ardah, A. (2012). Reforming Higher Education: The Case of Jordan's Hospitality and Tourism Sector. Journal of Teaching in Travel \& Tourism, 12(1), 105-117. doi:10.1080/15313220.2012.650104

İlban, M,. O. ve Köstekli, E. (2012). Turizm Eğitiminde Yaşanan Sorunların Öğrencilerin Okullarına Olan Bağlılık Düzeylerine ve Okul Devam Niyetlerine Etkileri. Turizm Eğitimi Konferans Workshop, 17-19 Ekim, (s. 199-213). Ankara, Turizm Bakanlığı Turizm Eğitimi Genel Müdürlüğü.

İlkiz, O. ve Hitay, O. (1992). Türkiye'de Turizm Eğitimindeki Sorunlar. Turizm Eğitimi Konferans Workshop, 9-11 Aralık, (s. 159-166.) Ankara, Turizm Bakanlığı Turizm Eğitimi Genel Müdürlüğü.

Kang, K.-S. (2011). A study on the recognition level of high school and university students and teachers about Culinary practice educa-tion. Korean Journal of Human Ecology, 20(2), 475-485. doi:10.5934/KJHE.2011.20.2.475

Karaman, S., Güven, Ö., Z. ve Ceylan, U. (2012). Meslek Yüksekokullarında Turizm eğitimi Alan Öğrencilerin Staj Uygulamalarında Karşılaştıkları sorunlar ve Çözüm Önerileri. Turizm Eğitimi Konferans-Workshop, 17-19 Ekim, (s. 226-233). Ankara, Turizm Ba-kanlığı Turizm Eğitimi Genel Müdürlüğü.

Ko, W.-H. (2010a). "Evaluating effective culinary learning of food and beverage department students at technology universities", World Transactions on Engineering and Technology Education (WIETE), 8(4), 477-481. Erişim adresi: http://www.wiete.com.au/ journals/WTE\&TE/Pages/Vol.8,\%20No.4\%20(2010)/12-18-KO-W-H.pdf

Ko, W.-H. (2010b). To evaluate the professional culinary competence of hospitality students. Journal of Culinary Science \& Tech-nology, 8(2-3), 136-146. doi: 10.1080/15428052.2010.511101

| Kastamonu Eğitim Dergisi, 2020, Vol. 28, No. 4| 
Ko, W.-H., ve Chiu, Y.-H. (2011). Developing teaching quality indicators for the culinary teacher in a university. World Transactions on Engineering and Technology Education, 9(2), 114-118. Erişim adresi: http://www.wiete.com.au/journals/WTE\&TE/Pages/ Vol.9,\%20No.2\%20(2011)/10-Ko-WH.pdf

Ko, W.-H. (2012). A study of the relationships among effective learning, professional competence, and learning performance in culinary field. Journal of Hospitality, Leisure, Sport \& Tourism Education, 11(1), 12-20. doi: 10.1016/j.jhlste.2012.02.010

Ko, W.-H., ve Chung, F.-M. (2015). Learning satisfaction for culinary students: The effect of teaching quality and professional expe-rience. International Journal of Vocational and Technical Education, 7(1), 1-13. doi: 10.5897/IJVTE2014.0158

Kılıç, G. ve Bayraktaroğlu, E. (2012). Lisans Düzeyinde Turizm Eğitimi ve Fakülte Bünyesinde Örgütleniş Biçimine Yönelik Bir Değer-lendirme. Turizm Eğitimi Konferans-Workshop, 17-19 Ekim, (s. 189-197). Ankara, Turizm Bakanlığı Turizm Eğitimi Genel Müdür-lüğü.

Kozak, M. (1992). Mesleki Turizm Eğitimi Veren Yükseköğretim Kurumlarında Ders Programlarının Hazırlanması. Turizm Eğitimi KonferansWorkshop, 9-11 Aralık, (s. 191-195). Ankara, Turizm Bakanlığı Turizm Eğitimi Genel Müdürlüğü.

Küçüktopuzlu, K., F. (2002). Turizm Eğitimi Veren Yüksekokulların Staj Programlarında Eşgüdüm sağlanması ve Çözüm Önerileri. Turizm Eğitimi Konferans-Workshop, 11-13 Aralık, (s. 335341). Ankara, Turizm Bakanlığı Turizm Eğitimi Genel Müdürlüğü.

Külahçı, Mehmet (1992). Turizm Sektöründe İşgücünün Mesleki Eğitimi. Turizm Eğitimi Konferans Workshop, 9-11 Aralık, (s. 105-113). Ankara, Turizm Bakanlığı Turizm Eğitimi Genel Müdürlüğü.

Li, L., ve Li, J. (2013). Hospitality education in China: A student career-oriented perspective. Journal of Hospitality, Leisure, Sport \& Tourism Education, 12(1), 109-117. doi: 10.1016/j.jhlste.2012.12.001

López-Bonilla, J. M., ve López-Bonilla, L. M. (2014). Holistic competence approach in tourism higher education: An exploratory study in Spain. Current Issues in Tourism, 17(4), 312-326. doi: 10.1080/13683500.2012.720248

Olcay, A. (2008). Türk Turizminde Eğitimin Önemi, Gaziantep University Journal of Social Sciences, 7(2), s. 383-390. Erişim adresi: http://dergipark.gov.tr/download/article-file/223496

Özmerzi, A. ve Ayata M., A. (1992). Akdeniz Üniversitesi Antalya Meslek Yüksekokulu Turizm ve Otelcilik Programı Öğrencilerinin Ağırlama Sektöründe Yaptığı Uygulama ve Stajlar. Turizm Eğitimi Konferans-Workshop, 9-11 Aralık, (s. 369-372). Ankara, Turizm Bakanlığı Turizm Eğitimi Genel Müdürlüğü.

Pelit, E., Keleş, Y., Çakır, M. ve Ayduğan, N. (2012). "2023 Turizm Stratejisindeki Mesleki Staj Hedefleri ve Mevcut Durumun Lisans Düzeyinde Turizm Eğitimi Açısından Değerlendirilmesi”. Turizm Eğitimi Konferans-Workshop, 17-19 Ekim, (ss. 32-47). Ankara, Turizm Bakanlığı Turizm Eğitimi Genel Müdürlüğü.

Pirnar, I. (2014). Tourism education universities in Turkey: Comparison of different structures and related Effects on education quality. ProcediaSocial and Behavioral Sciences, 116, 5070-5074. doi: 10.1016/j.sbspro.2014.01.1075

Solis, S. L. (2013). Preparing future industry leaders: a framework for Philippine tourism education. International Journal of Business Tourism Applied Sciences, 1(1), 37-46. Erişim adresi: http://www.ijbts-journal.com/images/main_1366796758/0082-Susan.pdf

Tabachnick, B. G. ve Fidell, L. S. (2012). Using Multivariate Statistics (6th Edition). Boston: Pearson.

Teng, C.-C., Horng, J.-S., ve Baum, T. (2013). Academic perceptions of quality and quality assurance in undergraduate hospitality, tourism and leisure programmes: A comparison of UK and Taiwanese programmes. Journal of Hospitality, Leisure, Sport \& Tourism Education, 13, 233-243. doi: 10.1016/j.jhlste.2012.06.002

Thitthongkam, T., ve Walsh, J. (2011). Tourism education at the tertiary level and competitive advantage: A comparison between Thai-land and Malaysia. Journal of Education and Vocational Research, 1(1), 26-35. Erişim adresi: https://ifrnd.org/journal/index.php/jevr/ article/view/5/5

Timur, A. (1992). Türkiye'de Turizm Eğitiminin Yapısı, Uygulanan Politikalar ve Sonuçları. Turizm Eğitimi Konferansı- Workshop, 9-11 Aralık, (s. 47-53). Ankara, Turizm Bakanlığı Turizm Eğitimi Genel Müdürlüğü.

Tuna, M. (2002). Turizm İşletmeciliği ve Otelcilik Alanında Eğitim Veren M.Y.O.'nın Sorunlarına illişkin Bir Araştırma. Turizm Eğitimi KonferansWorkshop, 11-13 Aralık (s. 43-52). Ankara, Turizm Bakanlığı Turizm Eğitimi Genel Müdürlüğü.

Türk İstatistik Enstitüsü, Temel İstatistikler, Erişim adresi: http://www.tuik.gov.tr/UstMenu.do?metod=temelist

Ural, A. ve Pelit, E. (2002). Türkiye'de Lisans Düzeyinde Turizm Eğitimi Veren Yüksek Öğretim Örgütlerinin Örgütleniş Biçimleri. Turizm Eğitimi Konferans-Workshop, 11-13 Aralık, (s. 75-85). Ankara, Turizm Bakanlığı Turizm Eğitimi Genel Müdürlüğü.

Wang, J., Ayres, H., ve Huyton, J. (2010). Is tourism education meeting the needs of the tourism industry? An Australian case study. Journal of Hospitality \& Tourism Education, 22(1), 8-14. doi: 10.1080/10963758.2010.10696964

Wang, J., Huyton, J., Gao, X., ve Ayres, H. (2010). Evaluating undergraduate courses in tourism management: A comparison between Australia and China. Journal of Hospitality, Leisure, Sports and Tourism Education, 9(2), 46-62. doi: 10.3794/johlste.92.258

World Economic Forum (2018), The Travel \& Tourism Competitiveness Report 2017, Paving the Way for a more Sustainable and Inclusive Future, Erişim adresi: https://www.weforum.org/reports/the-travel-tourism-competitiveness-report-2017 
Yang, J., ve Song, H. (2011). Tourism education programmes in Mainland China. AngloHigher, The Magazine of Global English Speaking Higher Education, 2, 8-9.

Yayla, Ö., Silik, C. E. ve Dülger, A. S. (2017). Turizm Lisans ve Önlisans Eğitiminde 2017 Yılı Sayısal Değerlendirmeler, Journal of Tourism and Gastronomy Studies, 5(4), 47-58. doi: 10.21325/jotags.2017.137

Yeşiltaş, M., Öztürk, Y., ve Hemmington, N. (2010). Tourism education in Turkey and implications for human resources. Anatolia: An International Journal of Tourism and Hospitality Research, 21(1), 55-71. doi: 10.1080/13032917.2010.9687090

Yüksel, A. ve Yüksel, F. (2002). Measurement of Tourists Satisfaction with Restaurant Services: A Segment-Based Approach, Journal of Vacation Marketing, 9(1), 52-68. doi: 10.1177/135676670200900104

Zengin, B. ve Türkseven, E. (2012). Turizm Lisans Eğitiminde Yaşanan Staj Sorunları ve Çözüm Önerileri. Turizm Eğitimi Kon-ferans-Workshop, 1719 Ekim (s. 249-269). Ankara, Turizm Bakanlığı Turizm Eğitimi Genel Müdürlüğü. 